\title{
Male Men1 heterozygous mice exhibit fasting hyperglycemia in the early stage of MEN1
}

\author{
Zhongxiuzi Gao, Li Zhang, Wenting Xie, Siqi Wang, Xiaorui Bao, Yuli Guo, \\ Houjian Zhang, Qingzhong Hu, Yi Chen, Zeen Wang, Maoqiang Xue and \\ Guanghui Jin
}

Department of Basic Medical Sciences, Medical College, Xiamen University, Xiamen, China
Correspondence should be addressed to $\mathrm{G}$ Jin or M Xue Email ghjin@xmu.edu.cn or xmq8887@xmu.edu.cn

\begin{abstract}
Multiple endocrine neoplasia type 1 (MEN1) is an autosomal dominant inherited syndrome characterized by multiple tumors in the parathyroid glands, endocrine pancreas and anterior pituitary. Recent clinical studies have revealed a strong association between MEN1 syndrome and the risk of developing diabetes mellitus; however, the underlying mechanisms remain unknown. In this study, heterozygous Men1 knockout (Men1+--) mice were used as MEN1 models to investigate MEN1associated glucose metabolic phenotypes and mechanisms. Heterozygous deficiency of Men1 in 12-month-old male mice induced fasting hyperglycemia, along with increased serum insulin levels. However, male Men1+/- mice did not show insulin resistance, as evidenced by Akt activation in hepatic tissues and an insulin tolerance test. Increased glucose levels following pyruvate challenge and expression of key gluconeogenic genes suggested increased hepatic glucose output in the male Men1+- mice. This effect could be partly due to higher basal serum glucagon levels, which resulted from pancreatic islet cell proliferation induced by heterozygous loss of Men1. Taken together, our results indicate that fasted male Men $1^{+/-}$mice, in the early stage of development of MEN1, display glucose metabolic disorders. These disorders are caused not by direct induction of insulin resistance, but via increased glucagon secretion and the consequent stimulation of hepatic glucose production.
\end{abstract}
Key Words
- Men1
- glucagon
- gluconeogenesis
- hepatic glucose output
- insulin resistance (2016) 230, 347-355

\section{Introduction}

Multiple endocrine neoplasia type 1 (MEN1) is an autosomal dominant inherited syndrome characterized by multiple occurrences of endocrine tumors affecting the parathyroid glands, endocrine pancreas and anterior pituitary (Thakker et al. 2012). Menin, encoded by MEN1, is a tumor suppressor, and its loss of function causes MEN1 syndrome (Marx 2005). It is widely expressed in various tissues, including metabolic tissues such as the pancreas and liver (Guru et al. 1999). In their study on preventing gestational diabetes in pregnant mice, Karnik and coworkers reported that menin expression in the islets is physiologically suppressed by prolactin (Karnik et al. 2007). Furthermore, acute ablation of Men 1 in $\beta$-cells could prevent and/or treat hyperglycemia in diabetic mice (Yang et al. 2010a,b). Cheng and coworkers (2011) and Cao and coworkers (2013) demonstrated that hepatocyte-specific 
knockout of Men1 in mice does not affect glucose metabolism during aging and under a high-fat diet (HFD). However, Wuescher and coworkers reported that liverspecific heterozygous deletion of Men1 leads to glucose intolerance in HFD-fed mice rather than standard diet-fed mice (Wuescher et al. 2011, 2012). These studies suggest that menin plays an important role in glucose metabolism.

MEN1 patients exhibit higher prevalence of impaired fasting glucose levels and diabetes mellitus (DM) (Wagner et al. 2005, McCallum et al. 2006, van Wijk et al. 2012). Clinical studies based on homeostasis model assessment (HOMA) have revealed that patients with MEN1 are insulin resistant (Wagner et al. 2005, McCallum et al. 2006, van Wijk et al. 2012). Heterozygous Men1 knockout (Men1+/-) mice develop endocrine tumors similar to those observed in MEN1 patients (Crabtree et al. 2001, Bertolino et al. 2003, Loffler etal.2007). However, it is currently unknown whether these mice show abnormalities in glucose homeostasis, similar to MEN1 patients. To investigate MEN1-associated glucose metabolic phenotypes and mechanisms and to better understand the clinical manifestations of MEN1, Men1 ${ }^{+/-}$mice were used as MEN1 models in this study.

Our data showed that heterozygous deletion of Men1 resulted in impairment of glucose metabolism in 12-month-old male mice; however, it did not induce insulin resistance. Instead, it promoted glucagon production and increased hepatic glucose output (HGO), which together contributed to increased glucose levels in Men1+/- males.

\section{Materials and methods}

\section{Animal model}

All animal protocols were approved by the Animal Ethics Committee of the Xiamen University. Men1 ${ }^{\Delta \mathrm{N} 3-8 /+}$ (C57BL/6) mice heterozygous for the Men1 locus $\left(M e n 1^{+-}\right)$were a gift from Francis Collins (National Human Genome Research Institute, Bethesda, MD, USA). They were housed in a pathogen-free environment in a $12 \mathrm{~h}$ light: $12 \mathrm{~h}$ darkness cycle and given free access to water and standard chow diet. Studies were conducted using the Men1+/- mice as a model for MEN1, with agematched wild-type $\left(M e n 1^{+/+}\right)$mice as controls. Because mice developed multiple endocrine tumors late in life (Crabtree et al. 2001, Bertolino et al. 2003, Loffler et al. 2007), Men1 $1^{+/-}$mice at the age of 12 months (the early stage of development of MEN1) and 18 months (the middle-advanced stage of development of MEN1) were used in this study. Mice were fasted for $24 \mathrm{~h}$, anesthetized with $1.2 \%$ avertin $(240 \mathrm{mg} / \mathrm{kg}$ body weight) and then their blood was collected by cardiac puncture. One hour before administration of the anesthetic, the mice were weighed and injected intraperitoneally with bromodeoxyuridine (BrdU; Sigma-Aldrich) in phosphatebuffered saline (PBS) at a dose of $50 \mathrm{mg} / \mathrm{kg}$ body weight. The whole pancreas and liver were harvested for histological and molecular biological analyses, respectively. Concentrations of fasting serum hormones, including insulin, glucagon, glucose-dependent insulinotropic polypeptide (GIP), glucagon-like peptide-1 (GLP-1), ghrelin, leptin, plasminogen activator inhibitor-1 (PAI-1) and resistin, were estimated with the Bio-Plex Pro Mouse Diabetes Standard 8-Plex Assay (Bio-Rad).

\section{Glucose tolerance test}

After an overnight fast, mice were weighed and injected intraperitoneally with a bolus of glucose $(2 \mathrm{~g} / \mathrm{kg}$ body weight). Blood glucose levels were determined from tail blood before and, at the indicated time points, after glucose injection with a OneTouch UltraEasy glucometer (LifeScan, Milpitas, CA, USA).

\section{Insulin tolerance test}

Mice were fasted for $5 \mathrm{~h}$ before receiving an intraperitoneal injection of insulin $(0.75 \mathrm{U} / \mathrm{kg})$ in PBS. Blood glucose concentrations were estimated in tail blood before and, at the indicated time points, after insulin injection.

\section{Pyruvate tolerance test}

Overnight fasted mice were injected intraperitoneally with sodium pyruvate ( $2 \mathrm{~g} / \mathrm{kg}$ body weight). Blood glucose values were tested from tail blood before and, at the indicated time points, after sodium pyruvate injection.

\section{Western blotting analysis}

After the indicated animal experiments, liver tissues were lysed in ice-cold radioimmunoprecipitation assay buffer (Beyotime Institute of Biotechnology, Nantong, China). Protein concentrations were determined with a BCA Protein Assay Kit (Pierce). Tissue lysates ( $50 \mu \mathrm{g}$ protein) were separated by $10 \%$ sodium dodecyl sulfate-polyacrylamide gel electrophoresis and electrophoretically transferred onto a polyvinylidene difluoride membrane. After blocking for $60 \mathrm{~min}$ at room temperature in Tris-buffered saline containing $0.1 \%$ Tween 20 and 5\% nonfat milk, the membranes were incubated overnight at $4^{\circ} \mathrm{C}$ with anti-pAkt

Published by Bioscientifica Ltd 
Table 1 Primers used for qPCR analysis.

\begin{tabular}{l} 
Sequence name \\
\hline$m G 6 p c-\mathrm{F}$ \\
$m G 6 p c-\mathrm{R}$ \\
$m P c k 1-\mathrm{F}$ \\
$m P c k 1-\mathrm{R}$ \\
mGapdh-F \\
mGapdh-R
\end{tabular}

\begin{tabular}{l}
\hline Primers \\
\hline 5'-GTGCAGCTGAACGTCTGTCTGT-3' \\
5'-TCCGGAGGCTGGCATTGT-3' \\
5'-GAACTGACAGACTCGCCCTATGT-3' \\
5'-GTTGCAGGCCCAGTTGTTG-3' \\
5'-AACAGCAACTCCCACTCTTC-3' \\
5'-CCTGTTGCTGTAGCCGTATT-3' \\
\hline
\end{tabular}

\begin{tabular}{c}
\hline Temperature $\left({ }^{\circ} \mathrm{C}\right)$ \\
\hline 63 \\
61 \\
62 \\
60 \\
58 \\
58 \\
\hline
\end{tabular}

\begin{tabular}{c}
\hline Size $(b p)$ \\
\hline 139 \\
165 \\
111
\end{tabular}

(Ser473) antibody (Cell Signaling, \#9271), anti-Akt antibody (Cell Signaling, \#9272), anti-pIRS-1 (Tyr632) antibody (Santa Cruz, sc-17196), or anti-GAPDH antibody (Epitomics, P04406). The membranes were washed thrice with Trisbuffered saline containing $0.1 \%$ Tween 2 and incubated with horseradish peroxidase-conjugated secondary antibodies, and then the protein levels were detected using an enhanced chemiluminescence kit (Millipore).

\section{Quantitative polymerase chain reaction analysis}

Total RNA was extracted from frozen liver tissues using TRIzol reagent (Invitrogen). One microgram of total RNA was reverse transcribed into cDNA using the PrimeScript RT Reagent Kit with gDNA Eraser (TaKaRa, Dalian,

A
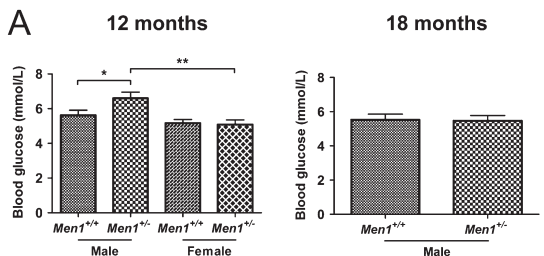

B
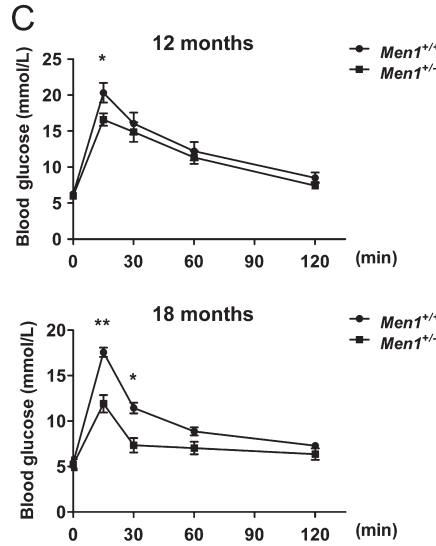

Figure 1

Male Men1+/- mice exhibit fasting hyperglycemia. (A) Blood glucose levels after $24 \mathrm{~h}$ of fasting in 12-month-old and 18-month-old mice $(n=20$ and 6 , respectively). (B) Serum insulin levels $24 \mathrm{~h}$ after fasting in 12 -month-old $M e n 1^{+/+}$and Men1+/- mice $(n=10)$. (C) Glucose tolerance test in 12-monthold vs 18 -month-old male mice $(n=6)$. Data are presented as the mean \pm S.E.M. ${ }^{*} P<0.05, * * P<0.01$. Printed in Great Britain
China) according to the manufacturer's instructions. Quantitative polymerase chain reaction (qPCR) was performed as described previously (Xu et al. 2013) using an ABI StepOne detection system (Applied Biosystems) with the primer sequences, which are listed in Table 1. Mouse Gapdh was used as an internal control.

\section{Immunohistochemistry}

Four-micrometer-thick sections of formalin-fixed, paraffin-embedded mouse pancreatic tissues were cut and placed consecutively onto silanized glass slides, and were routinely dewaxed and rehydrated. After rinsing with PBS, the sections were immersed in 3\% hydrogen peroxide solution for $10 \mathrm{~min}$ to block endogenous peroxidase activity. For DNA denaturation, sections were placed in $2 \mathrm{M} \mathrm{HCl}$ for $30 \mathrm{~min}$. Antigens were retrieved in $0.1 \%$ trypsin solution for $20 \mathrm{~min}$ at $37^{\circ} \mathrm{C}$. Nonspecific binding was prevented by incubation in 5\% normal goat serum for $15 \mathrm{~min}$ in a humidified chamber. The sections were

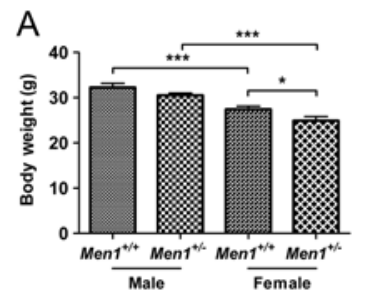

B

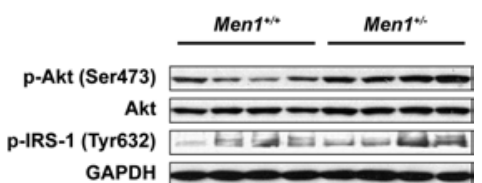

C
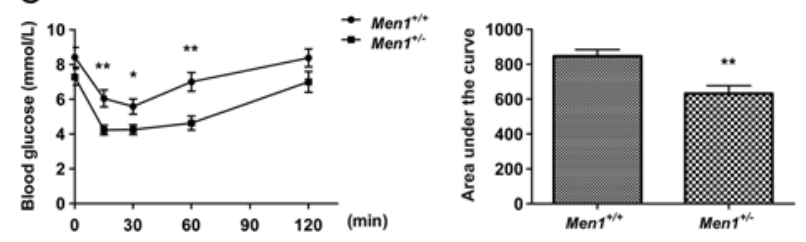

Figure 2

Insulin resistance is not induced in male Men1+/- mice. (A) Body weights of 12-month-old Men1+/+ and Men1+/- mice $(n=20)$. (B) The activity (phosphorylated serine 473 on Akt) and total levels of Akt and the tyrosine phosphorylation of IRS-1 in the liver were evaluated after $24 \mathrm{~h}$ of fasting $(n=10)$. (C) An insulin tolerance test was performed $(n=6)$, in 12-month-old Men1+/+ vs Men1 ${ }^{+/-}$male mice. Data are presented as the mean \pm S.E.M. ${ }^{*} P<0.05, * * P<0.01, * * * P<0.001$.

Published by Bioscientifica Ltd. 
then incubated with anti-BrdU antibody (Sigma, B2531) overnight at $4{ }^{\circ} \mathrm{C}$. After washing with PBS, antibody binding was detected with horseradish peroxidase-conjugated secondary antibody (Fuzhou Maixin Biotechnology Co, Ltd, Fuzhou, China) at $37^{\circ} \mathrm{C}$. The sections were visualized with diaminobenzidine solution, and then lightly counterstained with hematoxylin. As DNA denaturation is not required for anti-glucagon antibody (Abcam, ab10988), the antigens were retrieved in $10 \mathrm{mM}$ citrate buffer ( $\mathrm{pH}$ 6.0) for $15 \mathrm{~min}$ in a pressure cooker.

\section{Statistical analysis}

Data are presented as the mean \pm standard error of the mean (s.E.M.). For data at single time point, statistical differences were evaluated by unpaired Student's $t$-test or one-way analysis of variance (ANOVA), as appropriate. Datasets with multiple time points (e.g., GTT, ITT and PTT) were analyzed by repeated-measures ANOVA. A $P$ value of $<0.05$ was considered significant.

\section{Results}

\section{Male Men ${ }^{+/-}$mice exhibit fasting hyperglycemia}

Because the association between MEN1 and DM risk was primarily established by measuring fasting plasma glucose levels, we first evaluated the fasting glucose and insulin levels in mice at 12 months of age. As shown in Fig. 1A and $\mathrm{B}$, relative to wild-type controls, female $\mathrm{Men} \mathrm{1}^{+/-}$mice showed normal glucose regulation, whereas both fasting
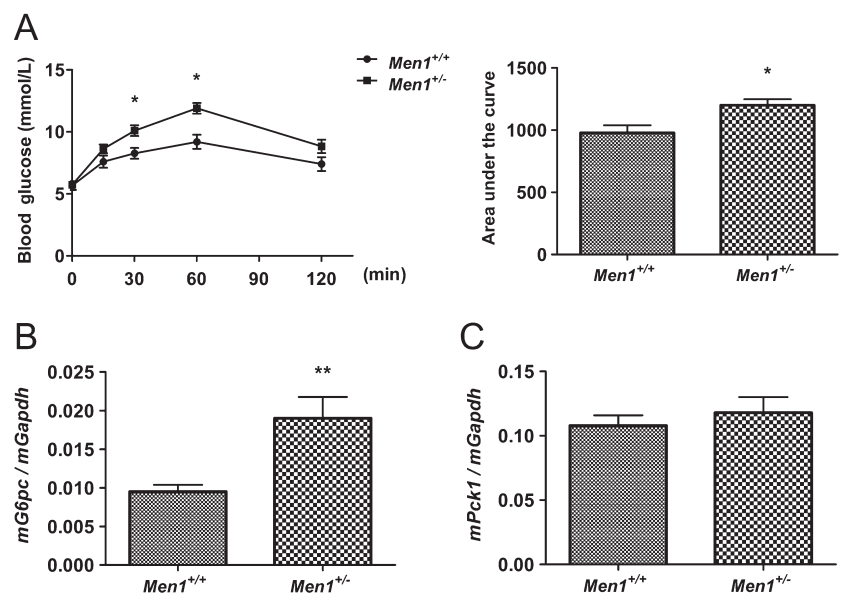

Figure 3

Male Men1+/- mice display increased hepatic glucose output. (A) Pyruvate tolerance test was performed $(n=6)$, and (B and C) the expression levels of gluconeogenic genes ( $m G 6 p c$ and $m P c k 1)$ in the liver were analyzed after $24 \mathrm{~h}$ of fasting $(n=10)$, in 12 -month-old Men $1^{+/+}$vs Men1 ${ }^{+/-}$male mice. Data are presented as the mean \pm S.E.M. ${ }^{*} P<0.05,{ }^{*} P<0.01$. blood glucose and serum insulin levels were significantly increased in male Men $1^{+/-}$mice. Nevertheless, heterozygous loss of Men1 in male mice did not induce significant impairment in the ability to clear a glucose load during GTT (Fig. 1C). To confirm impaired glucose metabolism in the middle-advanced MEN1 mouse model, we estimated blood glucose levels in the mice at 18 months of age. Surprisingly, fasting blood glucose level in the Men1+- male mice was similar to that in the Men1+/+ controls (Fig. 1A). A small but significant improvement in glucose tolerance was observed in Men1+/- male mice during GTT (Fig. 1C).

\section{Insulin resistance is not induced in male $M e n 1^{+/-}$mice}

The increased fasting blood glucose and serum insulin levels observed in humans with MEN1 is classically interpreted to be a consequence of insulin resistance. Obesity is known to cause insulin resistance and alterations in glucose metabolism (Kahn et al. 2006). In this study, no significant difference in body weight was observed between male Men1+/- mice and the Men1+/+ control group, and female $\mathrm{Men} \mathrm{1}^{+/-}$mice weighed even less than their controls (Fig. 2A). These findings suggest that the effect of heterozygous lack of Men1 on metabolism is not mediated by obesity.

Insulin resistance affects multiple tissues, including the liver and muscle (Bajaj \& Defronzo 2003). Overproduction of glucose by the liver, despite the presence of hyperinsulinemia, is primarily responsible for fasting hyperglycemia (Roden \& Bernroider 2003). Therefore, we examined insulin signaling in the liver by using the phosphorylation of Akt on serine 473 as a marker of insulin action. Relative to wild-type controls, the phosphorylation of serine 473 on Akt in the liver of $M e n 1^{+/-}$males is found to be significantly increased (Fig. 2B). No change in total Akt level was observed. Thus, the activity of Akt, a downstream target of insulin, is not inhibited in Men1 $1^{+-}$males. Consistent with this, we observed a significant increase in the tyrosine phosphorylation of insulin receptor substrate 1 (IRS-1), which is another crucial target of insulin signaling (Fig. 2B). These data demonstrate that the heterozygous absence of Men 1 does not cause direct impairment of insulin signaling in mice. To further investigate the effect of heterozygous ablation of Men1 on insulin sensitivity, we performed ITT in male mice. Insulin sensitivity was significantly enhanced in male Men1 $1^{+-}$mice (Fig. 2C). These data suggest that the increased glucose and insulin levels observed in the male Men1+/- mice are not caused by the underlying insulin resistance.

Published by Bioscientifica Ltd 


\section{Male Men1+/- mice display increased HGO}

The heterozygous deficiency of Men1 does not induce insulin resistance, but causes an increase in glucose and insulin levels. An obvious reason for this increase is that heterozygous knockout of Men1 in males promotes HGO, which is primarily derived from gluconeogenesis under fasting conditions (Wahren \& Ekberg 2007). Pyruvate is a major substrate for gluconeogenesis; therefore, to determine if the male Men1+/- mice exhibited increased glucose production, we performed PTT. As expected,
Men1 ${ }^{+/-}$mice exhibited higher blood glucose levels upon pyruvate administration, suggesting increased hepatic glucose production (Fig. 3A). The gluconeogenesis pathway is catalyzed by several key enzymes, including phosphoenolpyruvate carboxykinase (PCK1) and glucose-6-phosphatase (G6PC), which are the first and last rate-limiting enzymes of the process, respectively (Zhang et al. 2014). Consistent with the results of the PTT, hepatic mRNA levels of $G 6 p c$ were significantly higher in fasted Men1+/- mice than those in fasted Men1+/+ mice (Fig. 3B). Although Pck1 mRNA was also slightly
A

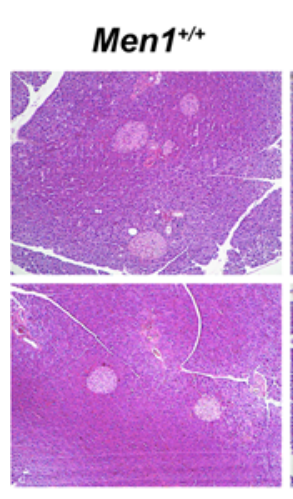

$B$

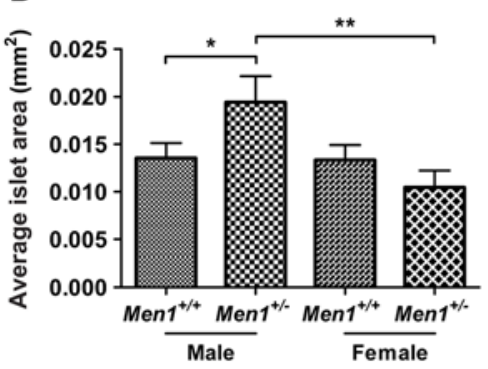

C
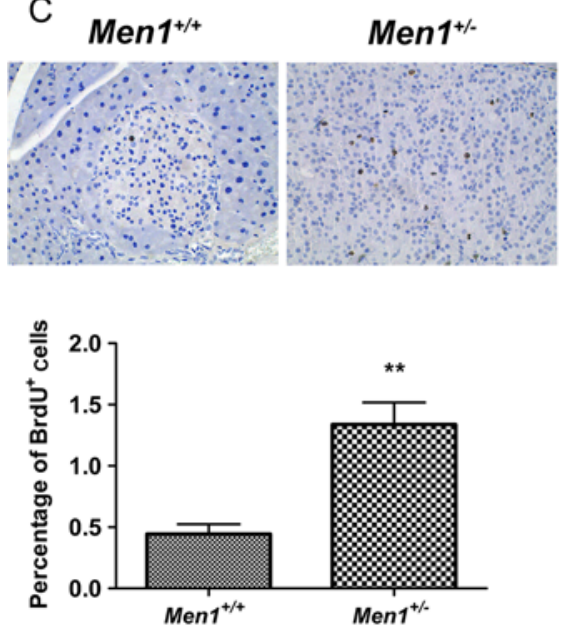

$\operatorname{Men}^{+/ /}$

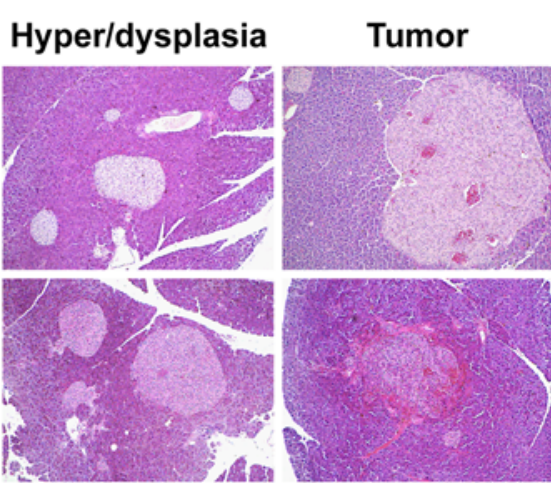

D

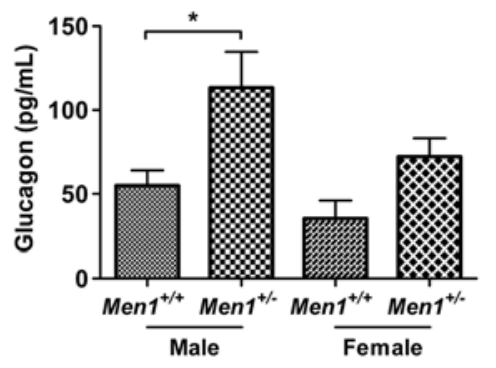

E
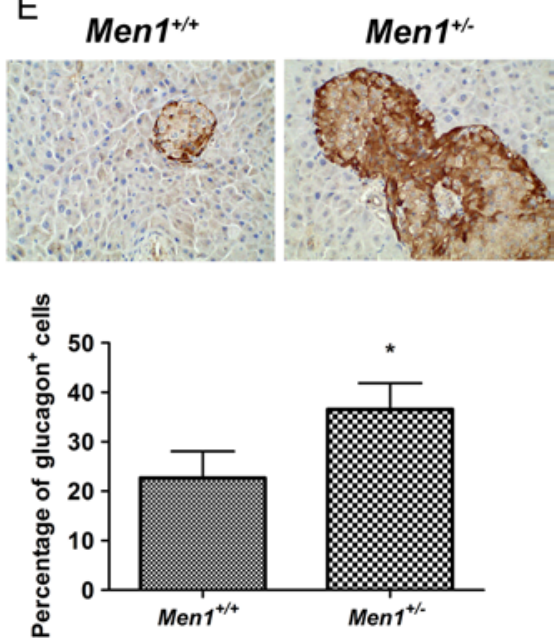

Figure 4

Fasting hyperglycemia is associated with islet proliferation and increased fasting serum glucagon levels in male Men1+/- mice. (A) Histological analysis was performed in pancreatic tissues by hematoxylin-eosin (H\&E) staining $(n=20)$. (B) Islet area was measured using the Image-Pro Plus software $(n=20)$ (Media Cybernetics, Silver Spring, MD, USA). (C) Proliferation of islet cells was assessed by immunohistochemical staining with BrdU antibody $(n=20)$, (D) Serum glucagon concentrations were examined $(n=10)$. (E) Glucagon immunohistochemical staining was analyzed in pancreatic tissues $(n=20), 24 \mathrm{~h}$ after fasting in 12-month-old Men1+/+ and Men1+/mice. Data are presented as the mean \pm S.E.M. $* P<0.05, * * P<0.01$. 
A

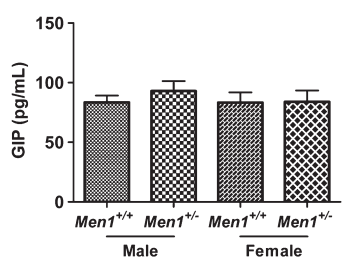

B

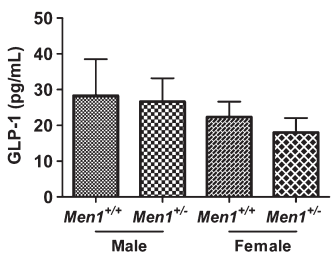

C

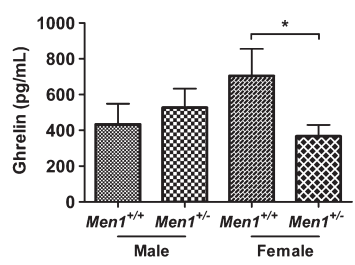

D

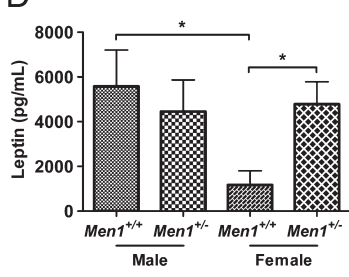

E

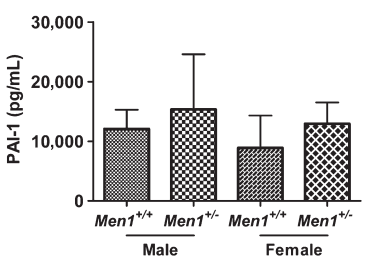

F

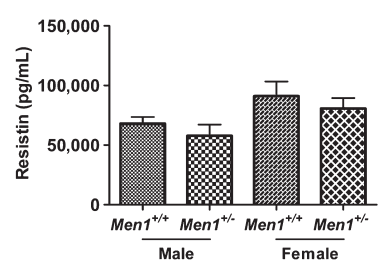

Figure 5

Other serum hormones $(\mathrm{A}-\mathrm{F})$ were evaluated after $24 \mathrm{~h}$ of fasting in 12-month-old $\mathrm{Men}^{+/+}$and Men $1^{1 /-}$ mice $(n=10)$. Data are presented as the mean \pm s.E.M. ${ }^{*} P<0.05, * * P<0.01$. upregulated, no significant difference between the two genotypes was observed (Fig. 3C). These data suggest that heterozygous loss of Men1 promotes gluconeogenesis and basal glucose production in the liver.

\section{Fasting hyperglycemia is associated with islet proliferation and increased fasting serum glucagon levels in male Men1+/- mice}

Glucagon regulates $\mathrm{HGO}$ in the fasted state by increasing gluconeogenesis and glycogenolysis in the liver (Hancock et al. 2010, Ramnanan et al. 2011). Men1 is crucial for the development (Fontaniere et al. 2008) and proliferation of pancreatic islets (Karnik et al. 2005, Schnepp et al. 2006), and therefore plays an important role in regulating basal insulin and glucagon secretion in mice. Under the experimental conditions of this study, we observed hyperplasia of pancreatic islets and development of islet tumors in Men1 ${ }^{+/-}$mice (Fig. 4A). Moreover, compared with Men1+/+ controls, male Men $1^{+/-}$mice displayed a marked increase in pancreatic islet area and cell proliferation (Fig. 4B and C). Higher fasting serum glucagon levels and glucagon immunohistochemical staining were observed in male Men $1^{+/-}$mice, indicating that the increased glucagon level contributed significantly to the elevated HGO and blood glucose levels in the male $\mathrm{Men} 1^{+/-}$mice under fasting conditions (Fig. 4D and E).

\section{Effects of other serum hormones involved in lipid and glucose metabolism}

To enhance our understanding of metabolic phenotypes in Men1+/- mice, we also examined the levels of other serum hormones involved in lipid and glucose metabolism
(Fig. 5). Female Men1+/- mice had higher serum leptin and lower serum ghrelin levels than the Men1+/+ controls (Fig. 5C and D). No significant differences were found in the levels of other hormones between the two genotypes.

\section{Discussion}

Glucose homeostasis involves the maintenance of a delicate balance between its production and utilization. Failure of glucose homeostasis leads to diseased states, including hyperglycemia and DM. Type 1 diabetes arises from autoimmune-induced $\beta$-cell damage (Bluestone et al. 2010), whereas type 2 diabetes develops mainly because of insulin resistance (Kahn et al. 2014). Eventually, insulin production is insufficient for maintaining normal blood glucose levels, leading to hyperglycemia and secondary complications, including cardiovascular disease, kidney dysfunction and blindness (Bluestone et al. 2010, Kahn et al. 2014). In the current animal studies, we observed that, compared with 12-month-old male Men1 ${ }^{+/+}$mice, male $\mathrm{Men1^{+/- }}$ mice had impaired glucose metabolism, characterized by high fasting blood glucose and serum insulin levels. These findings are consistent with previous clinical reports (Wagner et al. 2005, McCallum et al. 2006, van Wijk et al. 2012). Clinical studies based on HOMA have indicated that insulin resistance leads to glucose metabolic disorder in patients with MEN1 (Wagner et al. 2005, McCallum et al. 2006, van Wijk et al. 2012). However, we provide evidence that the effects of heterozygous loss of Men1 on glucose metabolism are not mediated by inducing insulin resistance. In the ITT, male Men1+/- mice displayed significantly enhanced glucose clearance rates. The activation of Akt in the liver also suggested that the Men $1^{+/-}$males were not insulin resistant.

Published by Bioscientifica Ltd 
The increase in blood glucose levels in the absence of insulin resistance suggests that heterozygous knockout of Men1 in male mice promotes HGO. Excess production of glucose from the liver is achieved by either increasing gluconeogenesis or by stimulating glycogenolysis (Roden \& Bernroider 2003). Under physiological conditions, during prolonged fasting, hepatic gluconeogenesis plays a crucial role in maintaining normal plasma glucose levels (Wahren \& Ekberg 2007). Compared with the Men1/++ controls, male Men1 ${ }^{+/-}$mice displayed increased glucose levels after pyruvate administration. Consistent with the results of the PTT, hepatic mRNA level of the gluconeogenic gene, G6pc, was significantly higher in fasted male Men1 ${ }^{+/-}$mice than in their control male mice, providing further evidence that heterozygous knockout of Men1 promotes gluconeogenesis and hepatic glucose production, leading to an elevation in fasting plasma glucose concentration.

The increased HGO observed in this study was unexpected, because the male Men $1^{+/-}$mice displayed increased glucose and insulin levels, which normally act to suppress HGO (Edgerton et al. 2006, Ramnanan et al. 2010). As Akt phosphorylation was activated in the livers of male Men1+/- mice, insulin resistance may not be the reason for the increased HGO. Therefore, the obvious reason for the increased HGO is the increase in glucagon levels in male Men1+/- mice, despite the high levels of glucose and insulin. In 12-month-old male Men1+/mice, increased fasting glucagon levels were observed as a result of pancreatic islet cell proliferation induced by heterozygous ablation of Men1. In mice, the majority of cells within the islets are insulin-secreting $\beta$-cells (approximately 65-75\%), whereas glucagon-secreting $\alpha$-cells represent less than $20 \%$ of the individual islet area (Brissova et al. 2005). Therefore, dilatation of $\alpha$-cells via proliferation would be expected to have a greater physiological impact on glucose homeostasis than dilatation of an equivalent or even greater number of $\beta$-cells. This would explain the increase in fasting serum glucagon concentration and, consequently, impaired fasting blood glucose, despite the elevated fasting serum insulin levels.

Male Men1+/- mice exhibited fasting hyperglycemia at the age of 12 months, but demonstrated improved glucose tolerance at the age of 18 months. Previous clinical studies on patients with MEN1 have revealed that most early islet lesions tested positive for glucagon, whereas the advanced hormone-secreting islet tumors detected in the same patients were mainly insulinomas (Anlauf et al. 2006, Perren et al. 2007). These results indicate that glucagon-positive early lesions may be replaced or overtaken by insulinomas and mixed islet tumors during tumorigenesis. This hypothesis is supported by the recent reports that Men1 ablation in $\alpha$-cells leads to the formation of insulinomas ( $\mathrm{Lu}$ et al. 2010, Shen et al. 2010), which might provide a possible explanation for the dynamic change in glucose metabolism in Men1 ${ }^{+/-}$males.

Although no difference in body weight was observed between the genotypes in male mice, female Men $1^{+/-}$ mice weighed significantly less than their controls and exhibited higher serum leptin and lower serum ghrelin levels. The reduction in body weight may have been caused by either a decrease in food intake or an increase in energy expenditure. Because leptin and ghrelin can act centrally to decrease and increase feeding, respectively, the higher leptin and lower ghrelin levels in female Men $1^{+/-}$mice may reflect their lower food intake (Klok et al. 2007, Nogueiras et al. 2008).

In this study, all mice were under fasting condition. Whether higher blood glucose levels emerge in female Men $1^{+/-}$mice challenged with feeding and whether refeeding alters the metabolic phenotype in male Men1+/- mice remain to be elucidated. Moreover, we noticed differences in glucose metabolic phenotypes and body weight between male and female mice. Currently, the reason(s) underlying the observed sexually dimorphic metabolic phenotypes remain unclear. Furthermore, studies on gonadectomized or ovariectomized mice need to be conducted to eliminate the influence of sex hormones.

In summary, we elucidated the glucose metabolic phenotype of mice exhibiting the early stage of development of MEN1. In male Men1 ${ }^{+/-}$mice, pancreatic islet proliferation induced by heterozygous knockout of Men1 increased fasting basal serum glucagon concentration. It subsequently promoted hepatic gluconeogenesis, resulting in impaired fasting blood glucose levels, despite an increase in insulin concentration and insulin sensitivity.

\section{Declaration of interest}

The authors declare that there is no conflict of interest that could be perceived as prejudicing the impartiality of the research reported.

\section{Funding}

This work was supported by the Natural Science Foundation of Fujian Province (grant number 2014J06019) and the China Postdoctoral Science Foundation (grant number 2015M570559).

Published by Bioscientifica Ltd. 


\section{Author contributions}

G-H $J$ and $M-Q X$ designed the experiments and revised the manuscript; Z-X-Z G, LZ, W-T X, S-Q W, X-R B, Y-L G and H-J Z performed the experiments and acquired the data; Q-Z H, Y C and Z-E W contributed to the separation of the desired tissues; Z-X-Z G, M-Q X and G-H J analyzed the data; and Z-X-Z G wrote the manuscript.

\section{Acknowledgements}

We thank Dr Francis Collins at the National Human Genome Research Institute (Bethesda, MD, USA) for providing the heterozygous Men1 locus $\left(\right.$ Men $\left.^{+/-}\right)$mice.

\section{References}

Anlauf M, Schlenger R, Perren A, Bauersfeld J, Koch CA, Dralle H, Raffel A, Knoefel WT, Weihe E, Ruszniewski P, et al. 2006 Microadenomatosis of the endocrine pancreas in patients with and without the multiple endocrine neoplasia type 1 syndrome. American Journal of Surgical Pathology 30 560-574. (doi:10.1097/ 01.pas.0000194044.01104.25)

Bajaj M \& Defronzo RA 2003 Metabolic and molecular basis of insulin resistance. Journal of Nuclear Cardiology 10 311-323. (doi:10.1016/ S1071-3581(03)00520-8)

Bertolino P, Tong WM, Galendo D, Wang ZQ \& Zhang CX 2003 Heterozygous Men1 mutant mice develop a range of endocrine tumors mimicking multiple endocrine neoplasia type 1. Molecular Endocrinology 17 1880-1892. (doi:10.1210/me.2003-0154)

Bluestone JA, Herold K \& Eisenbarth G 2010 Genetics, pathogenesis and clinical interventions in type 1 diabetes. Nature 464 1293-1300. (doi:10.1038/nature08933)

Brissova M, Fowler MJ, Nicholson WE, Chu A, Hirshberg B, Harlan DM \& Powers AC 2005 Assessment of human pancreatic islet architecture and composition by laser scanning confocal microscopy. Journal of Histochemistry and Cytochemistry 53 1087-1097. (doi:10.1369/ jhc.5C6684.2005)

Cao Y, Xue Y, Xue L, Jiang X, Wang X, Zhang Z, Yang J, Lu J, Zhang C, Wang W, et al. 2013 Hepatic menin recruits SIRT1 to control liver steatosis through histone deacetylation. Journal of Hepatology $\mathbf{5 9}$ 1299-1306. (doi:10.1016/j.jhep.2013.07.011)

Cheng P, Yang SS, Hu XG, Zhou XY, Zhang YJ, Jin G \& Zhou YQ 2011 Menin prevents liver steatosis through co-activation of peroxisome proliferator-activated receptor alpha. FEBS Letters 585 3403-3408. (doi:10.1016/j.febslet.2011.09.043)

Crabtree JS, Scacheri PC, Ward JM, Garrett-Beal L, Emmert-Buck MR, Edgemon KA, Lorang D, Libutti SK, Chandrasekharappa SC, Marx SJ, et al. $2001 \mathrm{~A}$ mouse model of multiple endocrine neoplasia, type 1, develops multiple endocrine tumors. PNAS 98 1118-1123. (doi:10.1073/pnas.98.3.1118)

Edgerton DS, Lautz M, Scott M, Everett CA, Stettler KM, Neal DW, Chu CA \& Cherrington AD 2006 Insulin's direct effects on the liver dominate the control of hepatic glucose production. Journal of Clinical Investigation 116 521-527. (doi:10.1172/ JCI27073)

Fontaniere S, Duvillie B, Scharfmann R, Carreira C, Wang ZQ \& Zhang CX 2008 Tumour suppressor menin is essential for development of the pancreatic endocrine cells. Journal of Endocrinology 199 287-298. (doi:10.1677/JOE-08-0289)

Guru SC, Crabtree JS, Brown KD, Dunn KJ, Manickam P, Prasad NB, Wangsa D, Burns AL, Spiegel AM, Marx SJ, et al. 1999 Isolation, genomic organization, and expression analysis of Men1, the murine homolog of the MEN1 gene. Mammalian Genome 10 592-596. (doi:10.1007/s003359901051)
Hancock AS, Du A, Liu J, Miller M \& May CL 2010 Glucagon deficiency reduces hepatic glucose production and improves glucose tolerance in adult mice. Molecular Endocrinology 24 1605-1614. (doi:10.1210/ me.2010-0120)

Kahn SE, Hull RL \& Utzschneider KM 2006 Mechanisms linking obesity to insulin resistance and type 2 diabetes. Nature $\mathbf{4 4 4} 840-846$. (doi:10.1038/nature05482)

Kahn SE, Cooper ME \& Del Prato S 2014 Pathophysiology and treatment of type 2 diabetes: perspectives on the past, present, and future. Lancet 383 1068-1083. (doi:10.1016/S0140-6736(13)62154-6)

Karnik SK, Hughes CM, Gu X, Rozenblatt-Rosen O, McLean GW, Xiong Y, Meyerson M \& Kim SK 2005 Menin regulates pancreatic islet growth by promoting histone methylation and expression of genes encoding p27Kip1 and p18INK4c. PNAS 102 14659-14664. (doi:10.1073/ pnas.0503484102)

Karnik SK, Chen H, McLean GW, Heit JJ, Gu X, Zhang AY, Fontaine M, Yen MH \& Kim SK 2007 Menin controls growth of pancreatic betacells in pregnant mice and promotes gestational diabetes mellitus. Science 318 806-809. (doi:10.1126/science.1146812)

Klok MD, Jakobsdottir S \& Drent ML 2007 The role of leptin and ghrelin in the regulation of food intake and body weight in humans: a review. Obesity Reviews 8 21-34. (doi:10.1111/j.1467-789x.2006.00270.x)

Loffler KA, Biondi CA, Gartside M, Waring P, Stark M, Serewko-Auret MM, Muller HK, Hayward NK \& Kay GF 2007 Broad tumor spectrum in a mouse model of multiple endocrine neoplasia type 1. International Journal of Cancer 120 259-267. (doi:10.1002/ijc.22288)

Lu J, Herrera PL, Carreira C, Bonnavion R, Seigne C, Calender A, Bertolino P \& Zhang CX 2010 Alpha cell-specific Men1 ablation triggers the transdifferentiation of glucagon-expressing cells and insulinoma development. Gastroenterology 138 1954-1965. (doi:10.1053/j.gastro.2010.01.046)

Marx SJ 2005 Molecular genetics of multiple endocrine neoplasia types 1 and 2. Nature Reviews Cancer 5 367-375. (doi:10.1038/nrc1610)

McCallum RW, Parameswaran V \& Burgess JR 2006 Multiple endocrine neoplasia type 1 (MEN 1) is associated with an increased prevalence of diabetes mellitus and impaired fasting glucose. Clinical Endocrinology 65 163-168. (doi:10.1111/j.1365-2265.2006.02563.x)

Nogueiras R, Tschop MH \& Zigman JM 2008 Central nervous system regulation of energy metabolism: ghrelin versus leptin. Annals of the New York Academy of Sciences 1126 14-19. (doi:10.1196/ annals.1433.054)

Perren A, Anlauf M, Henopp T, Rudolph T, Schmitt A, Raffel A, Gimm O, Weihe E, Knoefel WT, Dralle H, et al. 2007 Multiple endocrine neoplasia type 1 (MEN1): loss of one MEN1 allele in tumors and monohormonal endocrine cell clusters but not in islet hyperplasia of the pancreas. Journal of Clinical Endocrinology and Metabolism 92 1118-1128. (doi:10.1210/jc.2006-1944)

Ramnanan CJ, Edgerton DS, Rivera N, Irimia-Dominguez J, Farmer B, Neal DW, Lautz M, Donahue EP, Meyer CM, Roach PJ, et al. 2010 Molecular characterization of insulin-mediated suppression of hepatic glucose production in vivo. Diabetes 59 1302-1311. (doi:10.2337/ db09-1625)

Ramnanan CJ, Edgerton DS, Kraft G \& Cherrington AD 2011 Physiologic action of glucagon on liver glucose metabolism. Diabetes, Obesity and Metabolism 13 (Supplement 1) 118-125. (doi:10.1111/j.14631326.2011.01454.x)

Roden M \& Bernroider E 2003 Hepatic glucose metabolism in humans its role in health and disease. Best Practice \& Research Clinical Endocrinology \& Metabolism 17 365-383. (doi:10.1016/S1521690X(03)00031-9)

Schnepp RW, Chen YX, Wang H, Cash T, Silva A, Diehl JA, Brown E \& Hua X 2006 Mutation of tumor suppressor gene Men1 acutely enhances proliferation of pancreatic islet cells. Cancer Research $\mathbf{6 6}$ 5707-5715. (doi:10.1158/0008-5472.CAN-05-4518) http://joe.endocrinology-journals.org

DOI: 10.1530/JOE-16-0090
๑) 2016 Society for Endocrinology Printed in Great Britain
Published by Bioscientifica Ltd 
Shen HC, Ylaya K, Pechhold K, Wilson A, Adem A, Hewitt SM \& Libutti SK 2010 Multiple endocrine neoplasia type 1 deletion in pancreatic alpha-cells leads to development of insulinomas in mice. Endocrinology 151 4024-4030. (doi:10.1210/en.2009-1251)

Thakker RV, Newey PJ, Walls GV, Bilezikian J, Dralle H, Ebeling PR, Melmed S, Sakurai A, Tonelli F \& Brandi ML 2012 Clinical practice guidelines for multiple endocrine neoplasia type 1 (MEN1). Journal of Clinical Endocrinology and Metabolism 97 2990-3011. (doi:10.1210/ jc. 2012-1230)

van Wijk JP, Dreijerink KM, Pieterman CR, Lips CJ, Zelissen PM \& Valk GD 2012 Increased prevalence of impaired fasting glucose in MEN1 gene mutation carriers. Clinical Endocrinology 76 67-71. (doi:10.1111/j.1365-2265.2011.04166.x)

Wagner AM, Martin-Campos JM, Mayoral C, de Leiva A \& Blanco-Vaca F 2005 Patients with MEN-1 are more insulin-resistant than their non-affected relatives. European Journal of Internal Medicine $\mathbf{1 6}$ 507-509. (doi:10.1016/j.ejim.2005.09.008)

Wahren J \& Ekberg K 2007 Splanchnic regulation of glucose production. Annual Review of Nutrition 27 329-345. (doi:10.1146/annurev. nutr.27.061406.093806)

Wuescher L, Angevine K, Hinds T, Ramakrishnan S, Najjar SM \& Mensah-Osman EJ 2011 Insulin regulates menin expression, cytoplasmic localization, and interaction with FOXO1. American Journal of Physiology: Endocrinology and Metabolism 301 E474-E483. (doi:10.1152/ajpendo.00022.2011)

Wuescher L, Angevine K, Patel PR \& Mensah-Osman E 2012 Menin liver-specific hemizygous mice challenged with high fat diet show increased weight gain and markers of metabolic impairment. Nutrition \& Diabetes 2 e34. (doi:10.1038/nutd.2012.7)

Xu B, Li SH, Zheng R, Gao SB, Ding LH, Yin ZY, Lin X, Feng ZJ, Zhang S, Wang XM, et al. 2013 Menin promotes hepatocellular carcinogenesis and epigenetically up-regulates Yap1 transcription. PNAS 110 17480-17485. (doi:10.1073/pnas.1312022110)

Yang Y, Gurung B, Wu T, Wang H, Stoffers DA \& Hua X $2010 a$ Reversal of preexisting hyperglycemia in diabetic mice by acute deletion of the Men1 gene. PNAS 107 20358-20363. (doi:10.1073/ pnas.1012257107)

Yang Y, Wang H \& Hua X 2010b Deletion of the Men1 gene prevents streptozotocin-induced hyperglycemia in mice. Experimental Diabetes Research 2010 876701. (doi:10.1155/2010/876701)

Zhang P, Tu B, Wang H, Cao Z, Tang M, Zhang C, Gu B, Li Z, Wang L, Yang Y, et al. 2014 Tumor suppressor p53 cooperates with SIRT6 to regulate gluconeogenesis by promoting FoxO1 nuclear exclusion. PNAS 111 10684-10689. (doi:10.1073/pnas.1411026111)

Received in final form 26 June 2016

Accepted 18 July 2016

Accepted Preprint published online 18 July 2016 (c) 2016 Society for Endocrinology Printed in Great Britain
Published by Bioscientifica Ltd 